\title{
STUDIES ON THE
}

\section{TACHYPHYLAXIS TO NICOTINIC STIMULANT DRUGS IN THE PERFUSED HYPOGASTRIC GANGLION OF THE GUINEA-PIG}

\author{
G.A. BENTLEY \\ Department of Physiology, Monash University, Clayton, Vic. 3168, Australia
}

1 The guinea-pig hypogastric ganglion, perfused through its vasculature with physiological saline solutions, will respond repeatedly to nicotinic stimulant drugs injected at 4 min intervals into the perfusion stream. Stimulation is indicated by contraction of the vas deferens. After a varying number of doses of nicotinic stimulants, complete tachyphylaxis usually develops, and normally this persists for at least 1 hour. During this time, however, electrical stimulation of the hypogastric nerve is still fully effective.

2 Tachyphylaxis may be reversed for varying periods of time by all of the following procedures: (a) tetanic stimulation of the hypogastric nerve; (b) injection of large doses of histamine, methacholine, or potassium chloride; (c) perfusion with saline containing ouabain $0.1 \mu \mathrm{g} / \mathrm{ml}$ or $80-100 \mathrm{mM}$ lithium chloride, or, to a lesser extent, with potassium-free saline.

3 Tachyphylaxis is always re-established with further doses of nicotinic stimulants, except during perfusion with lithium solutions.

4 Atropine hastens the onset of tachyphylaxis, but does not prevent its reversal by hypogastric nerve stimulation or by histamine or potassium. However, it does prevent the reversal by methacholine and by lithium.

5 Tachyphylaxis occurs in decentralized ganglia, and can be reversed by histamine, methacholine, and by tetanic stimulation of the hypogastric ganglion. Hence tachyphylaxis and its reversal cannot be due to an effect on presynaptic fibres.

6 Potassium chloride stimulates the ganglion both before and after tachyphylaxis has developed to nicotinic drugs, and hence this is unlikely to be due to a depolarization block.

7 It is concluded that tachyphylaxis could be due to a prolonged ganglionic hyperpolarization.

\section{Introduction}

In 1972 , Bentley described a preparation of the hypogastric ganglion of the guinea-pig which can be perfused through its vasculature with physiological saline solutions. This ganglion can be stimulated either electrically via the hypogastric nerve or by the injection of nicotinic stimulant drugs into the perfusion stream. Both these procedures cause contractions of the vas deferens. While many properties shown by the hypogastric ganglion are similar to those of other, better known sympathetic ganglia, certain differences were also noted. For example, it is normally very difficult to demonstrate responses to non-nicotinic stimulant drugs in the hypogastric ganglion, though these have been repeatedly seen in the cat superior cervical ganglion (Trendelenburg, 1954; Jones, 1963; Smith, 1966a, b). Bentley (1972) also reported that after repeated doses of several nicotinic stimulants, given at $4 \mathrm{~min}$ intervals, tachyphylaxis usually developed to these drugs. However, at a time when the ganglion had become completely insensitive to the nicotinic drugs, electrical stimulation of the hypogastric nerve could still elicit a maximal contraction of the vas deferens.

This paper describes further studies aimed at elucidating the nature of this selective druginduced blockade. Evidence will be produced to show that it does not involve a presynaptic action of the nicotinic stimulants, nor is it likely to be due to a persistent depolarization of the ganglion cells. The tachyphylaxis is reversed by some, but not all, procedures that are known to prevent post-tetanic hyperpolarization in nervous tissue, 
and is accentuated by some other procedures known to increase hyperpolarization. Hence it is suggested that a persistent, drug-induced hyperpolarization is a possible explanation of the observations.

\section{Methods}

Male guinea-pigs (200-300 g body weight) were stunned and bled out. They were prepared for perfusion of the hypogastric ganglion as described by Bentley (1972). Briefly, this method involves the cannulation of the abdominal aorta with a polyethylene cannula, through which physiological saline is perfused at a rate of $1 \mathrm{ml} /$ minute. By appropriately placed ligatures, the perfusion stream is confined almost entirely to the hypogastric ganglion and the vasa deferentia. The vena cava is cannulated with another polyethylene tube to carry the effluent from the preparation. Both hypogastric nerves are dissected out down to the base of the seminal vesicles. The skinned body of the guinea-pig is then transected just below the level of the kidneys, and the anterior part discarded. The lower part is tied firmly to a perspex plate, and the preparation placed in a bath of physiological saline at $36^{\circ} \mathrm{C}$, bubbled with $95 \%$ oxygen: $5 \%$ carbon dioxide. A ligature around the base of one vas deferens (usually on the right side) prevents the perfusion fluid and injected drugs from reaching the smooth muscle of this organ. By stitching this ligature firmly to the muscles of the back, it is possible to record responses from only the upper, unperfused part of the vas deferens.

In some of these experiments, the contralateral vas deferens without a ligature around its base was used as a control. In this way it was possible to detect the effects of injected drugs on the smooth muscle of the vas deferens, and whether the ligature on the opposite vas deferens had impaired nerve conduction within the walls of the organ. However, it was rare to find that the ligated vas deferens gave significantly smaller responses to ganglion stimulant drugs or to electrical stimulation of the hypogastric nerve than did the opposite organ. Therefore in many of the later experiments the second vas deferens was removed and responses were recorded from only the unperfused vas deferens.

After removal of the testis, a cotton tie was attached to the epididymal end of the vas deferens for recording its contractions. In the earlier experiments this was done with a frontal-writing lever and a smoked drum. A tension of $1 \mathrm{~g}$ was applied to the organ, and magnification was four-fold. In the later work, the responses of the vas deferens were recorded semi-isometrically, with a flexible wooden lever attached to a Grass FT03B forcedisplacement transducer, with a Grass 5D polygraph. In these experiments, the organ was under a tension of 0.5 grams.

At the conclusion of all experiments ink was injected into the perfusion stream, and only those experiments were accepted in which there was no leakage, and the region of the hypogastric ganglion was clearly being perfused.

\section{Decentralization of ganglia}

Guinea-pigs were anaesthetized with ether or fluorothane; the abdominal cavity was opened with aseptic precautions by a low midline incision and one hypogastric nerve was divided by removing a piece about $5 \mathrm{~mm}$ long. The wound was sutured with cotton and the animals were allowed to recover. Twenty-four hours after the operation, the animals all appeared fully recovered and remained well until 2-5 weeks later when they were killed and used to provide perfused hypogastric ganglion preparations as described above. Decentralization of the ganglion was indicated by failure of the vas deferens to contract when the hypogastric nerve was stimulated central to the cut, though it would contract, if the electrodes were placed on the hypogastric ganglion. The seminal vesicle on the side of the transection was grossly distended.

The drugs used were dissolved in physiological saline, and were injected in a volume of $0.1 \mathrm{ml}$ into the perfusion stream. Nicotinic stimulants were given at 4 min intervals. Electrical stimulation of the hypogastric nerve was applied with platinum electrodes, using shocks of $0.1 \mathrm{~ms}$ duration, at a frequency of $50 \mathrm{~Hz}$ (unless otherwise specified) at just supramaximal voltage, for periods of 5-15 seconds.

The compositions of the various physiological saline solutions used are set out in Table 1. Drugs used were: atropine sulphate (Drug Houses of Australia); carbamylcholine chloride (BDH); 1,1-dimethyl-4' -phenylpiperazinium iodide (DMPP) (K \& K Labs); histamine acid phosphate (KochLight); hexamethonium bromide (Koch-Light); lithium chloride; mepyramine maleate (May \& Baker); nicotine hydrogen tartrate (BDH); ouabain octahydrate (Sigma); and tetramethyl ammonium bromide (TMA) (BDH).

\section{Results}

The effects of repeated doses of nicotinic stimulant drugs on the perfused hypogastric ganglion

The four nicotinic stimulant drugs used, carbamylcholine, DMPP, nicotine and TMA all caused the 
$\frac{8}{\frac{1}{x}}$

เ

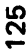

เก

n

8

응

हี<smiles>[131I-]</smiles>

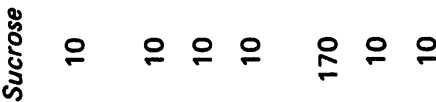

\ֶু

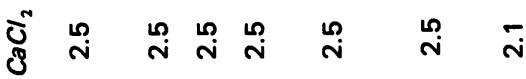

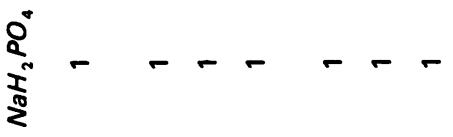

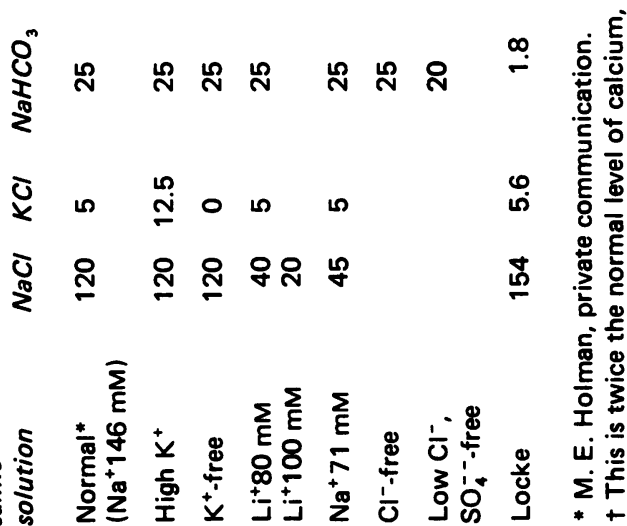

vas deferens to contract strongly when they were injected into the saline solution perfusing the hypogastric ganglion. The drug-induced contractions were usually almost as large as the response to supramaximal electrical stimulation of the hypogastric nerve at $50 \mathrm{~Hz}$, and were occasionally slightly larger. The four drugs were all approximately equipotent and the threshold dose for stimulation varied from 0.5 to $5.0 \mu \mathrm{g}$. However, when repeated threshold doses were used, the responses of the vas deferens tended to be erratic, and so a supramaximal dose of $20 \mu \mathrm{g}$ in $0.1 \mathrm{ml}$ was routinely used.

All four nicotinic stimulants caused some tachyphylaxis on repeated injection. In the majority of experiments the responses were reduced by $80 \%$ or more. In only three experiments out of 165 was no tachyphylaxis seen. The results are summarized in Table 2 .

Once tachyphylaxis had occurred there was never any sign of spontaneous recovery when the preparation was left undisturbed for periods of up to $1 \mathrm{~h}$, though if the dose of nicotinic stimulant was increased to $100 \mu \mathrm{g}$ after complete loss of sensitivity, small contractions of the vas deferens sometimes occurred, but these rapidly dwindled to zero again with repeated dosing.

Cross-tachyphylaxis amongst the four nicotinic stimulant drugs was complete.

As reported previously (Bentley, 1972), the vas deferens would still contract maximally in response to preganglionic electrical stimulation of the hypogastric nerve, even when the ganglion had become completely insensitive to the injected nicotinic stimulants. It was also found that, following a pre-ganglionic tetanus for 5-15 s at $50 \mathrm{~Hz}$, the response to a subsequent dose of any of the nicotinic drugs used was almost always restored, often to near the original size, and sometimes even above this (Table 3 ). This reversal of the tachyphylaxis did not occur if the electrical stimulation was applied post-ganglionically by direct field stimulation of the vas deferens, distal to the ligature at its base (Figure 1).

After restoration of the response, the nicotinic stimulant produced tachyphylaxis again, usually more rapidly than in the first instance, and preganglionic stimulation again reversed the block, though usually less completely than before.

The ability of a preganglionic tetanic stimulation to reverse the tachyphylaxis was still fully apparent if the next dose of nicotinic stimulant drug was delayed for 15-20 min after the electrical stimulation (Figure 1).

It was found that tachyphylaxis could be produced quite rapidly by perfusing the ganglion with TMA at a concentration of $5 \mu \mathrm{g} / \mathrm{ml}$. After an initial small contraction, there was no sign of 
Table 2 The development of tachyphylaxis to various agonist drugs after repeated dosing.

$\begin{array}{lccc}\text { Agonist } & \begin{array}{c}\text { No. of } \\ \text { experiments }\end{array} & \text { Degree of block } & \text { Mean no. of doses and range } \\ \text { Carbamylcholine } & 20 & 100 \%: 0 / 20 & 15.9(5-23) \\ & & >80<100 \%: 11 / 20 & 18.5(6-24) \\ \text { Carbamylcholine + atropine } & & <80 \%: 7 / 20 & (6,10) \\ & 7 & 0 \%: 2 / 20 & 6.6(2-10) \\ \text { DMPP } & & 100 \%: 3 / 7 & 12.5(11,14) \\ & & >80<100 \%: 2 / 7 & 13.5(10,17) \\ \text { DMPP + atropine } & >70<80 \%: 2 / 7 & 14.1(2-25) \\ & & 100 \%: 8 / 32 & 13.6(4-23) \\ \text { Nicotine } & & >80<100 \%: 15 / 32 & 15.4(8-23) \\ & 7 & <80 \%: 9 / 32 & 4.0(3,5) \\ \text { TMA + atropine } & 100 \%: 2 / 7 & 6.8(4-13) \\ & & >80<100 \%: 4 / 7 & 10 \\ & 15 & >70<80 \%: 1 / 7 & 5.2(2-8) \\ & & 100 \%: 5 / 15 & 19.6(7-38) \\ & & >80<100 \%: 10 / 15 & -\end{array}$

Table 3 Mean recovery of response to nicotinic stimulant drugs following preganglionic stimulation of the hypogastric nerve after tachyphylaxis had developed to these drugs.

$\begin{array}{lccc}\begin{array}{c}\text { Nicotinic } \\ \text { drugs }\end{array} & \begin{array}{c}\text { No. of } \\ \text { experiments }\end{array} & \begin{array}{c}\text { Mean \% increase and } \\ \text { following tetanic stimu }\end{array} \\ \text { Carbamylcholine } & 7 & 47.4 & (0-144) \\ \text { Carbamylcholine } & 3^{*} & 105.3^{*}(69-144) \\ \text { atropine } & 9 & 34.3(0-93) \\ \text { DMPP } & 3^{*} & 43.3^{*}(28-93) \\ & 12 & 63.7 & (0-116) \\ \text { DMPP + } & 3^{*} & 63.3^{*}(0-116) \\ \text { atropine } & 6 & 47.1 & (0-98) \\ \text { Nicotine } & 3^{*} & 94.1^{*}(90-98) \\ & 4 & 83 & (33-118) \\ \text { TMA } & 1^{*} & 85^{*} & \\ & 11 & 57.2 & (20-91) \\ \text { TMA + } & 6^{*} & 70.7^{*}(44-91) \\ \text { atropine } & 10 & 87.1(13-180) \\ \text { All agonists } & 2^{*} & 72 & (66-78)\end{array}$

\footnotetext{
* Experiments in which the tetanic stimulation was the first treatment used to reverse tachyphylaxis. Recovery expressed as \% of the maximal response to nicotinic stimulants before tachyphylaxis developed. Only those experiments have been included where greater than $75 \%$ tachyphylaxis occurred.
} 

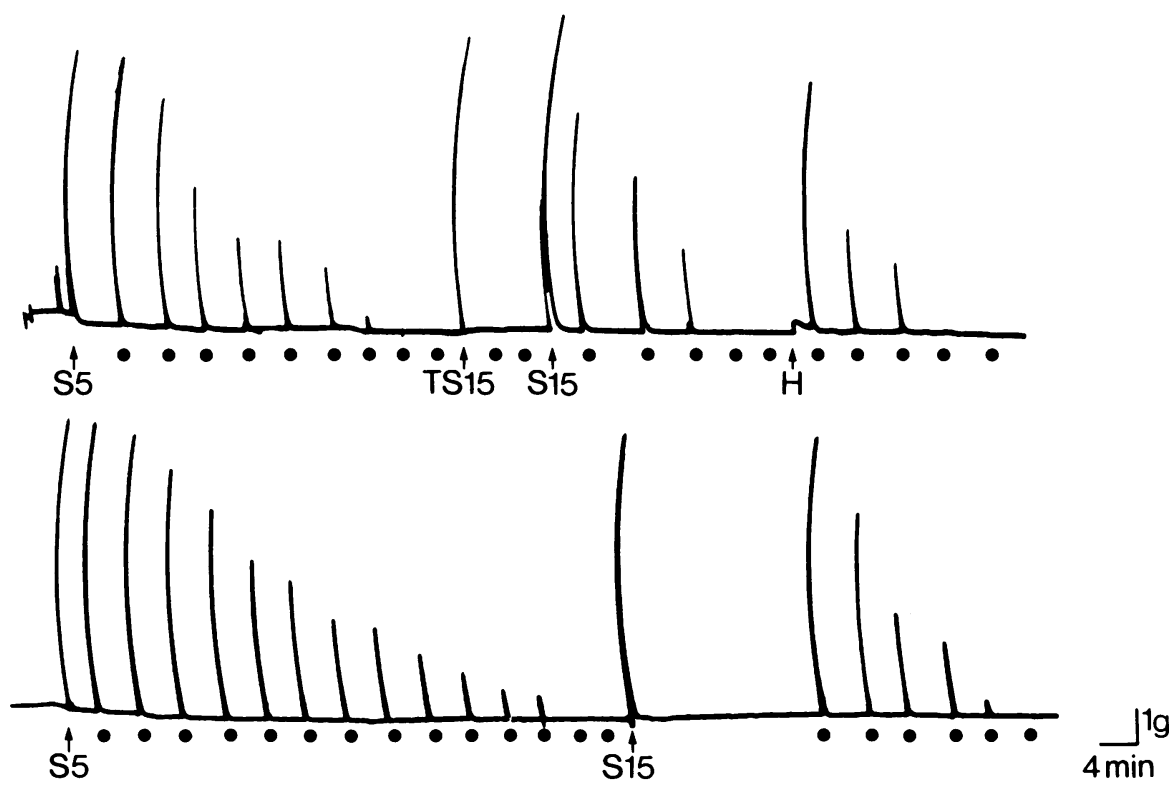

Fig. 1 Guinea-pig perfused hypogastric ganglion. Development of tachyphylaxis to tetramethyl ammonium bromide (TMA) given repeatedly at $4 \mathrm{~min}$ intervals, and its reversal by stimulation of the hypogastric nerve, or by histamine $(100 \mu \mathrm{g})$ given into the perfusion stream. Transmural (postganglionic) stimulation does not reverse the tachyphylaxis. S5, S15: electrical stimulation of the hypogastric nerve at $50 \mathrm{~Hz}$ for 5 or $15 \mathrm{~s}$, with supramaximal voltage. TS15: electrical stimulation, using the above parameters, applied to the base of the vas deferens, distal to the ligature. At dots, TMA $20 \mu \mathrm{g}$ injected into the perfusion stream, and at $H$, histamine $100 \mu \mathrm{g}$ was given.

stimulation for the following 20 minutes. TMA was then given in the usual $20 \mu \mathrm{g}$ dose and in all cases this was completely ineffective. In three out of four cases, stimulation of the hypogastric nerve still produced maximal contractions of the vas deferens, though this was depressed in the fourth case. However, there was no reversal of the blockade of the response to $20 \mu \mathrm{g}$ doses of TMA following the tetanic stimulation. When the TMA was removed from the perfusion fluid, the response to TMA $20 \mu \mathrm{g}$, given $15 \mathrm{~min}$ later, had returned to normal in all cases.

\section{Effects of atropine}

The inclusion of atropine $(1 \mu \mathrm{g} / \mathrm{ml})$ in the perfusion fluid, early in an experiment, had only a very small depressant effect on the response to electrical stimulation of the hypogastric nerve, or to nicotinic stimulants. However, atropine did reduce the number of doses of nicotinic drugs required to produce tachyphylaxis. Furthermore, if atropine was added after the preparation had been perfused for $1-1.5 \mathrm{~h}$, it immediately abolished the response to a dose of any of the nicotinic stimulants, whether or not they had been added during this preliminary period of perfusion. Atropine added late in the experiment only slightly depressed the response to electrical stimulation of the hypogastric nerve, but it did not prevent it from restoring the sensitivity of the ganglion to the nicotinic stimulants (Figure 2). On the other hand, hexamethonium $(10 \mu \mathrm{g} / \mathrm{ml})$ completely blocked responses both to nicotinic stimulant drugs and to electrical stimulation of the hypogastric nerve, whenever it was added to the preparation.

Effects of histamine and methacholine on tachyphylaxis

It was previously reported (Bentley, 1972) that even large doses of histamine or methacholine usually cause little stimulation of the hypogastric ganglion. However, it was found in the present study that, if these substances were injected in doses of $100 \mu \mathrm{g}$ into the perfusion stream after tachyphylaxis to nicotinic stimulant drugs had occurred, the tachyphylaxis was reversed. Histamine usually produced a more complete reversal than did methacholine, and in addition, the latter 

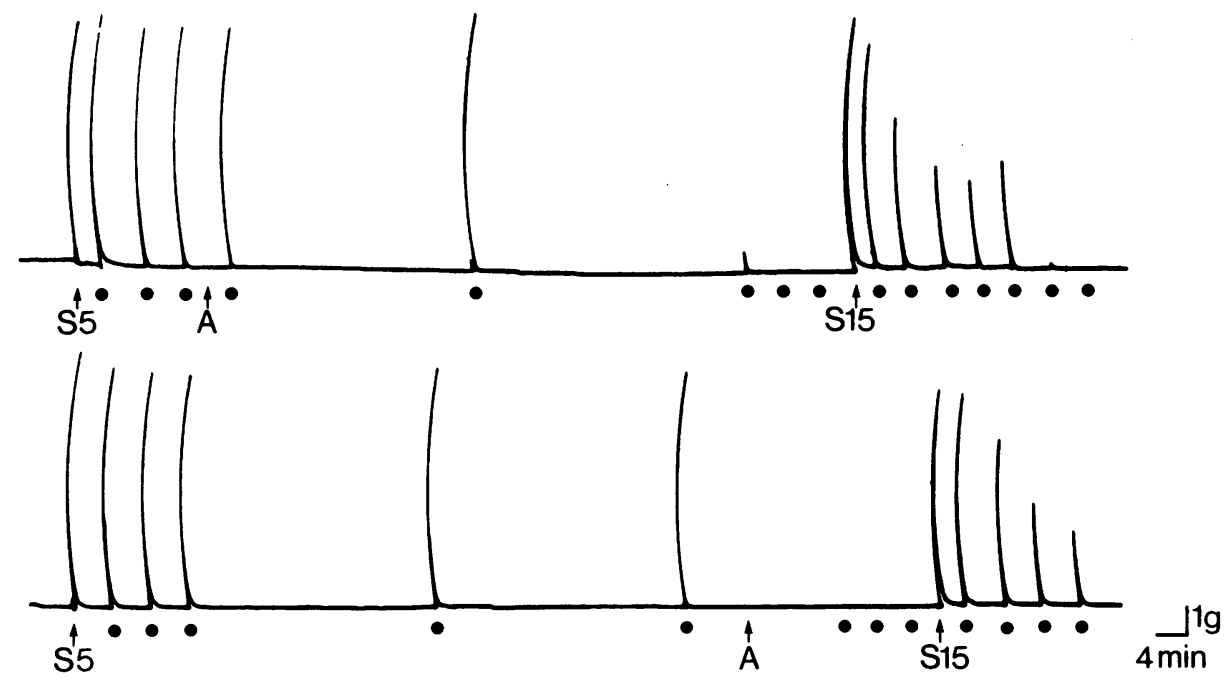

Fig. 2 Guinea-pig perfused hypogastric ganglion. Effects of atropine added at different times after the beginning of the experiment, on the response to tetramethyl ammonium bromide (TMA). S5, S15: electrical stimulation of the hypogastric nerve at $50 \mathrm{~Hz}$ for 5 or $15 \mathrm{~s}$ with supramaximal voltage. At dots, TMA $20 \mu \mathrm{g}$ injected into the perfusion stream. At $A$, atropine added to the perfusion stream to a concentration of $1 \mu \mathrm{g} / \mathrm{ml}$.

Atropine added early in the experiment did not affect the response to TMA until it had been present for more than $30 \mathrm{~min}$, but if added more than $1 \mathrm{~h}$ after the experiment had begun, it abolished the effect of TMA. In both cases the effects of TMA were restored after tetanic stimulation of the hypogastric nerve.

drug had little effect against the tachyphylaxis caused by carbamyl choline, though it was effective against the other three agonists. In all cases, tachyphylaxis could be re-established with the stimulant drug. After tachyphylaxis had redeveloped, it could be reversed a second or third time, though the later reversals, as with those produced by preganglionic electrical stimulation, were usually smaller than the first reversal. Histamine and methacholine still produced complete reversal of tachyphylaxis when the next dose of nicotinic drug was delayed until 15-20 min later (Figure 3).

In the presence of atropine $(1 \mu \mathrm{g} / \mathrm{ml})$, methacholine caused very little reversal of the tachyphylaxis, though both histamine and electrical stimulation of the hypogastric nerve were still effective (Table 4 \& Figure 2). Mepyramine $(1 \mu \mathrm{g} / \mathrm{ml})$ in the perfusion fluid blocked the reversal by histamine, but not by the other two agents.

\section{Investigations into the nature of the tachyphylaxis}

Perfusion of the ganglion with either nicotine $(10 \mu \mathrm{g} / \mathrm{ml})$ or hexamethonium $(50 \mu \mathrm{g} / \mathrm{ml})$ always completely abolished the response to both nicotinic stimulant drugs and to electrical stimulation of the hypogastric nerve. But, as described above, after repeated doses of $20 \mu \mathrm{g}$ nicotine or the other three nicotinic stimulant drugs, the response to electrical stimulation of the hypogastric nerve is not depressed, while the effects of the nicotinic stimulants are selectively abolished.

It seemed possible that the tachyphylaxis could have one of several explanations, and experiments were performed to determine whether it was due to any of the following: (a) a presynaptic effect of the nicotinic stimulants (McKinstry, Koenig, Koelle \& Koelle, 1963; Krstic, 1972) leading perhaps to the exhaustion of transmitter stores; (b) a prolonged ganglionic depolarization; (c) a prolonged ganglionic hyperpolarization.

a. Studies in chronically decentralized ganglia. Of 12 chronically decentralized preparations studied, eight responded well to nicotinic stimulant drugs, two of these in the presence of atropine $(1 \mu / \mathrm{ml})$. All the preparations that responded to nicotinic stimulants developed tachyphylaxis with repeated dosing, nicotine causing the most rapid block as in the normal preparation. There was no indication that the decentralized preparations behaved differently towards the nicotinic stimulants than did the normal ganglia. Furthermore, both histamine and methacholine caused substantial reversal of the tachyphylaxis, though electrical stimulation of 

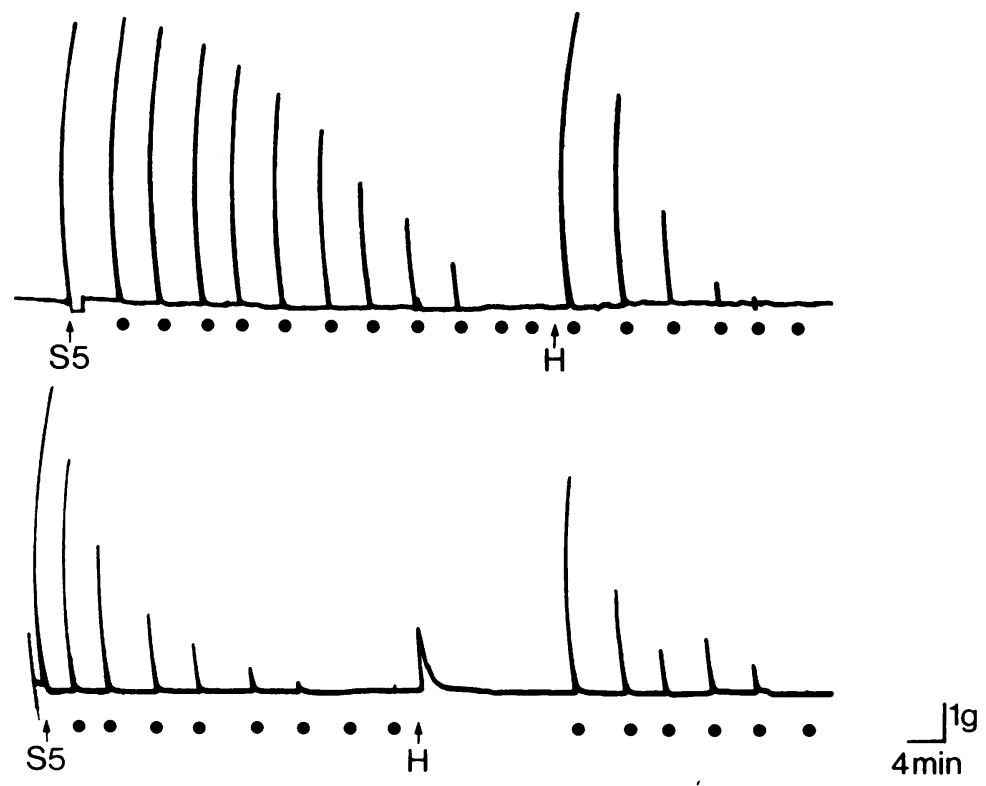

Fig. 3 Guinea-pig perfused hypogastric ganglion. The ability of histamine to reverse the tachyphylaxis to tetramethyl ammonium bromide (TMA), even after a delay of 20 minutes. Symbols as in Figure 1.

Table 4 Mean recovery of response to nicotinic stimulant drugs following a dose of either histamine or methacholine $(100 \mu \mathrm{g})$ after tachyphylaxis had developed to nicotinic stimulant drugs.

\begin{tabular}{|c|c|c|c|c|c|c|}
\hline \multirow{2}{*}{$\begin{array}{c}\text { Nicotinic } \\
\text { drug }\end{array}$} & \multirow{2}{*}{$\begin{array}{l}\text { No. of } \\
\text { experiments } \\
\qquad \begin{array}{l}9 \\
5^{*}\end{array}\end{array}$} & \multicolumn{2}{|c|}{$\begin{array}{c}\% \text { increase } \\
\text { following histamine }\end{array}$} & \multirow{2}{*}{$\begin{array}{l}\text { No. of expts } \\
\qquad \begin{array}{l}7 \\
3^{*}\end{array}\end{array}$} & \multicolumn{2}{|c|}{$\begin{array}{c}\% \text { increase } \\
\text { following methacholine }\end{array}$} \\
\hline & & $\begin{array}{l}47.2 \\
71\end{array}$ & 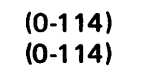 & & $\begin{array}{r}16.7 \\
2.3\end{array}$ & $\begin{array}{l}(0-93) \\
(0-7)\end{array}$ \\
\hline $\begin{array}{l}\text { Carbamylcholine + } \\
\text { atropine }\end{array}$ & ${ }^{11} 7^{*}$ & $\begin{array}{l}48.8 \\
50.4\end{array}$ & $\begin{array}{l}(0-110) \\
(0-110)\end{array}$ & $\begin{array}{l}7 \\
2^{*}\end{array}$ & $\begin{array}{r}4 \\
14\end{array}$ & $\begin{array}{l}(0-18) \\
(10-18)\end{array}$ \\
\hline DMPP & $\begin{array}{l}7 \\
5 *\end{array}$ & $\begin{array}{l}57.6 \\
62^{*}\end{array}$ & $\begin{array}{r}(0-100) \\
(20-100)\end{array}$ & $\begin{array}{l}6 \\
1^{*}\end{array}$ & $\begin{array}{l}41.8 \\
50\end{array}$ & $(0-93)$ \\
\hline $\begin{array}{l}\text { DMPP + } \\
\text { atropine }\end{array}$ & $\begin{array}{l}7 \\
5^{*}\end{array}$ & $\begin{array}{l}53.3 \\
53.8^{*}\end{array}$ & $\begin{array}{l}(0-93) \\
(0-93)\end{array}$ & $\begin{array}{l}5 \\
1 *\end{array}$ & $\begin{array}{l}0 \\
0\end{array}$ & \\
\hline Nicotine & $\begin{array}{l}4 \\
2 *\end{array}$ & $\begin{array}{l}59.7 \\
89 *\end{array}$ & $\begin{array}{r}(0-114) \\
(85-114)\end{array}$ & $6^{*}$ & 45.9 & $(0-91)$ \\
\hline TMA & $\begin{array}{l}14 \\
10^{*}\end{array}$ & $\begin{array}{l}47.8 \\
57.1^{*}\end{array}$ & $\begin{array}{l}(0-110) \\
(0-110)\end{array}$ & $\begin{array}{c}13 \\
3^{*}\end{array}$ & $\begin{array}{l}29.1 \\
49.6\end{array}$ & $\begin{array}{r}(0-95) \\
(20-95)\end{array}$ \\
\hline $\begin{array}{l}\text { TMA + } \\
\text { atropine }\end{array}$ & $\begin{array}{l}6 \\
5^{*}\end{array}$ & $\begin{array}{l}55 \\
66^{*}\end{array}$ & $\begin{array}{l}(0-149) \\
(0-149)\end{array}$ & $\begin{array}{l}7 \\
1 *\end{array}$ & $\begin{array}{l}0 \\
0\end{array}$ & \\
\hline
\end{tabular}

* Experiments where either histamine or methacholine were used as the first treatment to reverse tachyphylaxis. Recovery expressed as a \% of the maximal response to nicotinic stimulants before tachyphylaxis occurred. Only those experiments have been included where greater than $75 \%$-tachyphylaxis had occurred. 
the hypogastric ganglion was less effective than is hypogastric nerve stimulation in the normal preparations. These results are set out in Table 5 .

b. Action of potassium chloride on normal ganglia. The injection of $1 \mathrm{mg}$ of $\mathrm{KCl}$ dissolved in $0.1 \mathrm{ml}$ physiological saline into the ganglia usually caused the vas deferens to contract, though this contraction was seldom as large as the response to electrical stimulation of the hypogastric nerve, or to the nicotinic drugs. When complete tachyphylaxis to these drugs had occurred, $\mathrm{KCl}$ still caused ganglionic stimulation in most cases, although the response was usually slightly smaller than before tachyphylaxis had occurred. $\mathrm{KCl}$, like histamine and methacholine, reversed the tachyphylaxis, and atropine did not affect this reversal (Fig. 4 \& Table 6).

c. Effects of ouabain and lithium chloride. Gebber \& Volle (1966) and Jaramillo \& Volle (1968a) have shown that several nicotinic stimulant drugs, including TMA, cause hyperpolarization of the cat superior cervical ganglion, and a concomitant block of transmission. Jaramillo \& Volle (1968b) later showed that this hyperpolarization was prevented or reversed by pretreatment of the ganglion with either ouabain or lithium chloride though the blockade of ganglionic transmission still occurred. It seemed interesting therefore to test the effects of these two substances on the tachyphylaxis and its reversal.

In seven experiments, ouabain $(0.1 \mu \mathrm{g} / \mathrm{ml})$ was

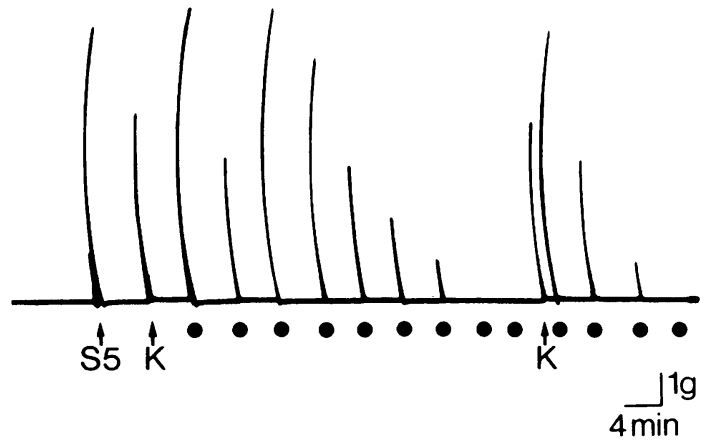

Fig. 4 Guinea-pig perfused hypogastric ganglion. The ability of $\mathrm{KCl}$ to stimulate the ganglion before and after tachyphylaxis to tetramethyl ammonium bromide (TMA), and to reverse the tachyphylaxis. S5: electrical stimulation of the hypogastric nerve as in Figure 1. $\mathrm{K}$, injection of $1 \mathrm{mg} \mathrm{KCl}$ into the perfusion stream. TMA, $20 \mu \mathrm{g}$, injected at dots.

perfused through the ganglion after complete tachyphylaxis to TMA had developed. In five cases, recovery commenced immediately, reached a peak after 2-10 doses of TMA and then slowly declined. The mean maximum recovery was $73 \%$ (33-130\%) of the original response to TMA.

Various experiments with lithium were conducted. The preparation was first perfused with the conventional saline solution, and tachyphylaxis was produced to either TMA or DMPP.

Table 5 The response of chronically decentralized hypogastric ganglia to nicotinic stimulants, and the reversal of tachyphylaxis in them.

\begin{tabular}{|c|c|c|c|c|c|}
\hline \multirow[b]{2}{*}{ Agonist } & \multirow{2}{*}{$\begin{array}{l}\text { No. responding } \\
\text { well to nicotinic } \\
\text { stimulant drug }\end{array}$} & \multirow{2}{*}{$\begin{array}{l}\text { No. of doses and } \\
\text { degree of } \\
\text { tachyphylaxis }\end{array}$} & \multicolumn{3}{|c|}{ \% reversal of tachyphylaxis by: } \\
\hline & & & Tetanic stim. & Hist. & Methachol \\
\hline DMPP & $1 / 1$ & 17 : 82\% & 64 & 65 & 100 \\
\hline $\begin{array}{l}\text { DMPP + } \\
\text { atropine }\end{array}$ & $1 / 1$ & $15: 92 \%$ & 44 & 45 & - \\
\hline Nicotine & $1 / 2$ & $4: 100 \%$ & 0 & 0 & - \\
\hline TMA & $4 / 7$ & $\begin{array}{c}10: 100 \% \\
7: 96 \% \\
8: 80 \% \\
15: 95 \%\end{array}$ & $\begin{array}{l}0 \\
0 \\
0 \\
-\end{array}$ & $\begin{array}{r}5 \\
84 \\
70 \\
137\end{array}$ & $\begin{array}{r}32 \\
70 \\
90 \\
100\end{array}$ \\
\hline $\begin{array}{l}\text { TMA + } \\
\text { atropine }\end{array}$ & $1 / 1$ & $\begin{array}{c}\text { atropine added after } 17 \\
\text { doses: } 100 \%\end{array}$ & 60 & 60 & - \\
\hline $\begin{array}{l}\text { All } \\
\text { agonists }\end{array}$ & $8 / 12$ & & $\begin{array}{l}3 / 7 \\
\bar{x}_{3}=56\end{array}$ & $\begin{array}{c}6 / 7 \\
\bar{x}_{6}=66.7\end{array}$ & $\begin{array}{c}5 / 5 \\
\bar{x}_{5}=78.4\end{array}$ \\
\hline
\end{tabular}

The figures in the last column are expressed as \% of the original response to the nicotinic stimulant before tachyphylaxis. $(-)$ indicates not tested. 
When blockade was complete the perfusion fluid was changed to one of the following solutions: saline in which 80 or $100 \mathrm{~mm}$ lithium chloride replaced an equimolar amount of sodium chloride, or where $160 \mathrm{mM}$ sucrose replaced $80 \mathrm{mM}$ sodium chloride. Dosing with the nicotinic stimulant was then continued at the usual $4 \mathrm{~min}$ intervals for 20-60 minutes.

In all cases, perfusion with saline containing $80 \mathrm{mM} \mathrm{LiCl}$ rapidly reversed the tachyphylaxis to DMPP (8 experiments) and to TMA (12 experiments). The degree of recovery varied from $50-113 \%$ of the original maximal response in normal saline, and the time taken to achieve this maximum varied from $4 \mathrm{~min}$ (i.e. the first dose in the $\mathrm{LiCl}$ solutions) to $36 \mathrm{~min}$ (i.e. after nine doses). A similar result was seen in six experiments in which $100 \mathrm{mM} \mathrm{LiCl}$-saline was used. In seven of these 26 cases, the response to DMPP or TMA subsequently declined to zero, but in the remainder, the responses were well maintained for 40-60 minutes. If the perfusion solution was then changed back to normal saline, the responses to TMA rapidly failed again, and could be restored by perfusing with lithium solution (Figure 5). If the ganglion was perfused with a solution containing $40 \mathrm{mM} \mathrm{NaCl}$ plus $160 \mathrm{mM}$ sucrose instead of the LiCl-solution, no recovery of the tachyphylaxis to TMA occurred (five experiments). In six other experiments, when tachyphylaxis to TMA had occurred, the ganglion was perfused with the 80 or $100 \mathrm{mM} \mathrm{LiCl}$-saline for $20 \mathrm{~min}$ before the next addition of TMA. There was no significant reduction in the number of doses of TMA necessary to produce maximum reversal of blockade. These results are set out in Table 7 .

If atropine was added to the perfusion fluid after tachyphylaxis had been reversed by lithium chloride, the responses to TMA were immediately abolished again (Figure 5).

\section{Effects of altering potassium levels}

In the absence of potassium, poststimulation hyperpolarization is depressed or abolished in the rabbit cervical sympathetic trunk (Ritchie \& Straub, 1957) and vagus (Rang \& Ritchie, 1968). Consequently the effects of perfusing the hypogastric ganglion with potassium-free saline were studied.

In four out of five experiments it was found that, after complete tachyphylaxis to TMA had been produced, perfusion with potassium-free saline restored the responses to TMA $(0-72 \%$ recovery, mean $=41.6 \%$ ). However, in all cases, failure soon occurred again with continued dosing. Stimulation of the hypogastric nerve then caused a second recovery in two of these cases.

\section{Effects of treatments known to accentuate post- tetanic hyperpolarization in nerves}

If the tachyphylaxis to nicotinic stimulants was due to a prolonged hyperpolarization, it might be expected that procedures which increase hyperpolarization would hasten the onset of tachyphylaxis, and perhaps prevent its reversal by stimulation of the hypogastric nerve etc. Therefore, the ganglion was perfused with the following solutions: saline containing $12.5 \mathrm{mM}$ potassium (Ritchie \& Straub, 1957); Locke solution (Holmes, 1962); and salines in which the chloride ion had been replaced with sulphate (Rang \& Ritchie, 1968 ) or methyl sulphate.

Raised potassium. In four experiments, after control responses had been obtained to TMA and electrical stimulation of the hypogastric nerve, the preparation was perfused for $20 \mathrm{~min}$ with saline containing $12.5 \mathrm{mM}$ potassium. Injections of TMA $(20 \mu \mathrm{g})$ were then given every 4 minutes. In one

Table 6 The effect of potassium chloride before and after tachyphylaxis to nicotinic stimulants had occurred, and its ability to reverse tachyphylaxis.

\begin{tabular}{|c|c|c|c|c|c|}
\hline \multirow[b]{3}{*}{$\begin{array}{c}\text { Nicotinic } \\
\text { agonist }\end{array}$} & \multirow[b]{3}{*}{$\begin{array}{c}\text { No. of } \\
\text { experiments }\end{array}$} & \multirow{3}{*}{$\begin{array}{l}\text { Dose } \\
K C l \\
\text { (mg) }\end{array}$} & \multicolumn{2}{|c|}{ Mean size of response } & \multirow{3}{*}{$\begin{array}{l}\% \text { increase in } \\
\text { response to nicotinic } \\
\text { drug after } \mathrm{KCl}\end{array}$} \\
\hline & & & to & & \\
\hline & & & $\begin{array}{c}\text { before } \\
\text { tachyphylaxis }\end{array}$ & $\begin{array}{c}\text { after } \\
\text { tachyphylaxis }\end{array}$ & \\
\hline \multirow[t]{2}{*}{ Nicotine } & 1 & 0.75 & - & 111 & 0 \\
\hline & 3 & 1.0 & $88(49-127)$ & $36.3\left(21^{\prime}-53\right)$ & $86 \quad(16-182)$ \\
\hline TMA & $\begin{array}{l}2 \\
4\end{array}$ & $\begin{array}{l}0.37 \\
1.0\end{array}$ & $\overline{50}(0-90)$ & $\begin{array}{rr}0 & \\
52 & (0-137)\end{array}$ & $\begin{aligned} 3.5 & (0,7) \\
74.5 & (9-140)\end{aligned}$ \\
\hline $\begin{array}{l}\text { TMA + } \\
\text { atropine }\end{array}$ & $\begin{array}{l}2 \\
3\end{array}$ & $\begin{array}{l}0.37 \\
1.0\end{array}$ & $\overline{72}(0-110)$ & $\begin{array}{l}52(44,60) \\
47.3(19-93)\end{array}$ & $\begin{array}{l}77.5(75,80) \\
66.0(50-81)\end{array}$ \\
\hline
\end{tabular}

In all cases, $>90 \%$ tachyphylaxis to the nicotinic stimulants was produced. 

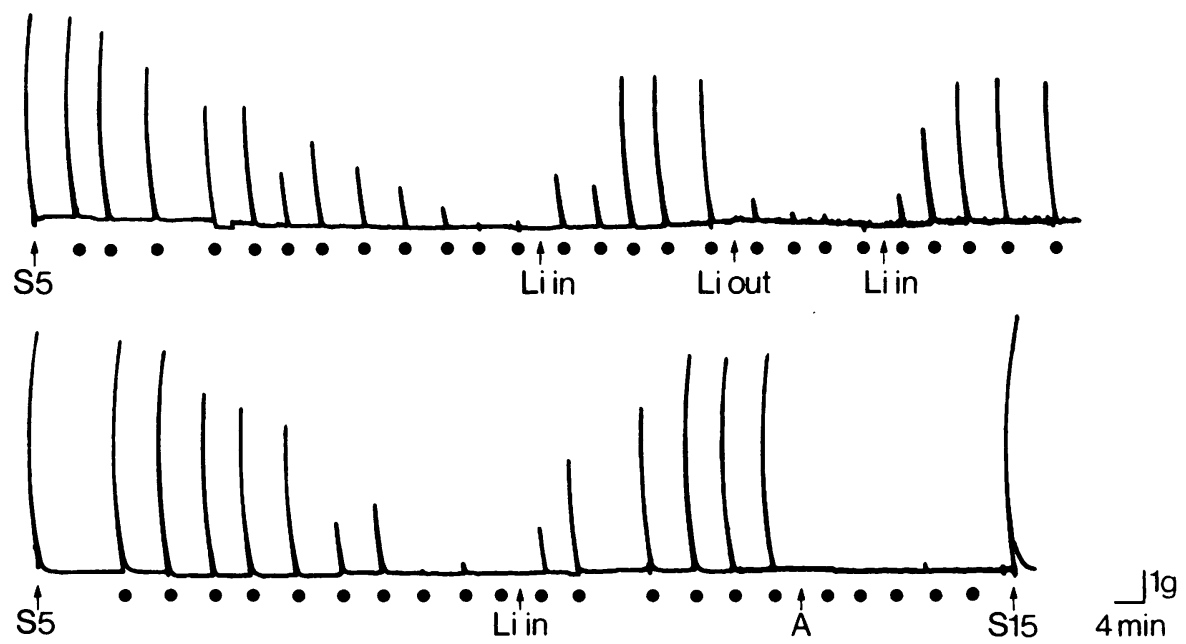

Fig. 5 Guinea-pig perfused hypogastric ganglion. The ability of lithium-containing saline to reverse the tachyphylaxis to tetramethyl ammonium bromide (TMA), (20 $\mu \mathrm{g}$ at dots) and the action of atropine in blocking it. S5, S15: electrical stimulation of the hypogastric nerves, as in Figure 1 . At $L i$ in, the ganglion was perfused with saline containing $100 \mathrm{mM} \mathrm{LiCl}$, and at $\mathrm{Li}$ out, the perfusion fluid was returned to normal saline without lithium. At A, atropine was added to the perfusion fluid at a concentration of $1 \mu \mathrm{g} / \mathrm{ml}$. The effect of lithium is rapidty reversed by perfusing with normal saline, and by atropine, though the ganglion still responds to electrical stimulation of the hypogastric nerve.

Table 7 The effect of perfusing physiological saline containing sodium chloride $40 \mathrm{mM}$ plus sucrose $160 \mathrm{mM}$, or sodium chloride $\mathbf{2 0}$ or $\mathbf{4 0} \mathrm{mM}$ plus lithium chloride 100 or $80 \mathrm{mM}$ on the tachyphylaxis produced by dimethylphenylpiperazinium iodide (DMPP) or tetramethylammonium bromide (TMA)

\begin{tabular}{|c|c|c|c|c|c|}
\hline Agonist & $\begin{array}{c}\text { No. of } \\
\text { experiments }\end{array}$ & $\begin{array}{c}\text { Composition of } \\
\text { saline }\end{array}$ & $\begin{array}{l}\text { Max. } \\
\text { recovery } \\
\text { (mean and } \\
\text { range) }\end{array}$ & $\begin{array}{l}\text { No. of doses } \\
\text { to max. res. } \\
\text { (mean and } \\
\text { range) }\end{array}$ & Comments \\
\hline TMA & 3 & $\begin{array}{l}40 \mathrm{mM} \mathrm{NaCl} \\
160 \mathrm{mM} \text { sucrose }\end{array}$ & $\begin{array}{l}\text { no } \\
\text { recovery }\end{array}$ & - & • \\
\hline TMA & 12 & $\begin{array}{l}40 \mathrm{mM} \mathrm{NaCl} \\
80 \mathrm{mM} \mathrm{LiCl}\end{array}$ & $\begin{array}{l}79.9 \% \\
(50-113 \%)\end{array}$ & $\begin{array}{c}3.8 \\
(1-6)\end{array}$ & $\begin{array}{l}\text { In four expts. responses } \\
\text { declined to zero after } \\
\text { recovery. Some small } \\
\text { fall-off in two others }\end{array}$ \\
\hline TMA & 6 & $\begin{array}{l}20 \mathrm{mM} \mathrm{NaCl} \\
100 \mathrm{mM} \mathrm{LiCl}\end{array}$ & $\begin{array}{c}79.1 \% \\
(60-98 \%)\end{array}$ & $\begin{array}{l}4.7 \\
(2-7)\end{array}$ & $\begin{array}{l}\text { In one expt. responses } \\
\text { declined to zero after } \\
\text { recovery }\end{array}$ \\
\hline TMA & $\begin{array}{l}4 \\
2\end{array}$ & $\begin{array}{l}20 \mathrm{mM} \mathrm{NaCl} \\
100 \mathrm{mM} \mathrm{LiCl} \\
40 \mathrm{mM} \mathrm{NaCl} \\
80 \mathrm{mM} \mathrm{LiCl}\end{array}$ & $\begin{array}{l}85.8 \% \\
(74-100 \%)\end{array}$ & $\begin{array}{l}2.5 \\
(2-4) \\
5\end{array}$ & $\begin{array}{l}\text { Li perfused for } 20 \mathrm{~min} \\
\text { before TMA given }\end{array}$ \\
\hline DMPP & 8 & $\begin{array}{l}40 \mathrm{mM} \mathrm{NaCl} \\
80 \mathrm{mM} \mathrm{LiCl}\end{array}$ & $\begin{array}{l}86.8 \% \\
(62-103 \%)\end{array}$ & $\begin{array}{l}4.0 \\
(1-9)\end{array}$ & $\begin{array}{l}\text { No recovery in one } \\
\text { other case. In two } \\
\text { expts. recovery was } \\
\text { followed by fall-off to } \\
\text { zero }\end{array}$ \\
\hline
\end{tabular}


case, complete block occurred after 17 doses of TMA, while in the other three, no reduction was seen after 10,11 or 15 doses, respectively. In two of these experiments the perfusion was then changed to $2.5 \mathrm{~mm}$ potassium saline, when failure immediately occurred in both, with recovery again in $12.5 \mathrm{~mm}$ potassium. Stimulation of the hypogastric nerve during the perfusion with high potassium did not affect the response to a subsequent dose of TMA. Hence there is little sign that raised potassium accentuates tachyphylaxis.

Locke solution. It was found that when the ganglion was perfused with Locke solution, complete tachyphylaxis to TMA occurred after a mean of $4.2(2-9)$ doses in four experiments. In only one of these did a hypogastric tetanus or histamine reverse this tachyphylaxis. In two other experiments, Locke solution was perfused for $20 \mathrm{~min}$ before giving TMA. In both cases, the first response to the agonist was either markedly or completely depressed, though stimulation of the hypogastric nerve was still as effective as in normal saline. It was concluded that the effect of Locke solution was not to hasten tachyphylaxis, but rather to desensitize the ganglion to TMA.

Replacement of chloride with sulphate or methyl sulphate. After perfusing the ganglion for $20 \mathrm{~min}$ with chloride-free sulphate solution, the response to TMA was only slightly smaller than in the control saline. Results were rather inconclusive as the onset of tachyphylaxis in the solution was very irregular. One hundred \% block occurred in four out of seven cases after a mean of 5.5 doses (2-13), but had not occurred after 11-17 doses in the remaining cases. Where block did occur, it was reversed both by hypogastric nerve stimulation and histamine.

With methyl sulphate ( $2.5 \mathrm{mM}$ chloride), again there was no very clear-cut evidence of accelerated tachyphylaxis. In four cases $100 \%$ block was produced (mean no. of doses 11.8, range 4-22 doses) and in these, hypogastric nerve stimulation gave a brief recovery, and histamine a rather more prolonged one.

\section{Discussion}

Nicotine in high doses has long been known to block transmission through autonomic ganglia (Langley \& Dickinson, 1889; Langley, 1891). Paton \& Perry (1953) showed that large doses of both acetylcholine and TMA, given into the blood supply of the cat superior cervical ganglion, caused depolarization of the ganglion and blockade of transmission lasting for about 4 minutes. Nicotine produced a much longer transmission block, though the period of depolarization lasted only about 3 minutes. Later work by Gebber \& Volle (1966) and Jaramillo \& Volle $(1968 \mathrm{a}, \mathrm{b})$ has shown that TMA, DMPP and acetylcholine also produce transmission blockade with a preliminary depolarization and a later hyperpolarization phase.

In the present study, repeated injections of nicotinic stimulant drugs, including nicotine, produced contractions of the vas deferens which exhibited tachyphylaxis. Even when the response to the drugs themselves had completely disappeared, ganglionic transmission remained intact. However, large doses of nicotine $(300 \mu \mathrm{g})$, or continuous perfusion $(10 \mu \mathrm{g} / \mathrm{ml})$ did block ganglionic transmission.

It is not immediately clear why this selective block should occur, but several explanations might be advanced. It is possible that the ganglion cells could have two populations of receptors, one of which responds to the injected drugs, and the other which is stimulated only by released transmitter. It would be necessary to postulate that this latter group of receptors was inaccessible to the nicotinic stimulants, and thus escaped the desensitizing action of the repeated dosing. However, it is difficult to reconcile this theory with the observation that both hexamethonium and high doses of nicotine rapidly block responses to both nicotinic stimulants and to nerve stimulation. A second possible explanation could be that only some ganglion cells respond to injected agonist drugs while all respond to nerve stimulation. In this case, it would also be necessary to assume that after a proportion of the cells had become insensitive, a maximal contraction of the vas deferens could still be obtained when the remaining cells were able to fire. Holman, Muir, Szurszewski \& Yonemura (1971) found that only $80 \%$ of the cells they studied in the guinea-pig hypogastric ganglion would fire spikes in response to iontophoreticallyapplied acetylcholine or nicotine. A third explanation could be that the nicotinic stimulants acted presynaptically (McKinstry et al., 1963; Krstic, 1972) to release transmitter from a small, labile pool, and that after repeated dosing, this pool became depleted. A further postulation necessary for this theory would be that nerve stimulation released transmitter from a different store. However, this theory is untenable, since the decentralized ganglia respond very similarly to normal ganglia to nicotinic stimulants, and develop tachyphylaxis that can be reversed by several of the agents that are also effective in the normal ganglia.

The tachyphylaxis might have resulted from a prolonged ganglionic depolarization, although Takeshige \& Volle (1964) have stated that this is only likely to occur with very high. doses of 
acetylcholine-like agents. Also, in the present study, it was shown that, after complete tachyphylaxis had occurred to the nicotinic stimulants, the ganglion would still respond to electrical stimulation of the hypogastric nerve, and to injected $\mathrm{KCl}$. Trendelenburg (1957) has shown that the ganglion-stimulating action of $\mathrm{KCl}$ is abolished during the early, depolarizing phase of nicotine block, but returns during the later, competitive phase. Furthermore, in the present study, $\mathrm{KCl}$ was usually effective in reversing the drug-induced tachyphylaxis.

A prolonged hyperpolarization would seem to be a more likely explanation for the tachyphylaxis, though the very long duration (more than one hour) is difficult to understand. Gebber \& Volle (1966), and Jaramillo \& Volle (1968a, b) have shown that several nicotinic stimulants, including TMA and DMPP, can cause a late hyperpolarization of the cat superior cervical ganglion, lasting several minutes, together with a block of transmission during this time. On the other hand, tetanic stimulation of the preganglionic nerve can also cause a period of hyperpolarization, lasting for some minutes (Takeshige \& Volle, 1964) yet in the present study this procedure was found to be very effective in restoring the response to a dose of a nicotinic stimulant given 2 minutes later. However, several procedures which are known to prevent posttetanic hyperpolarization were shown to prevent or reverse the tachyphylaxis in the hypogastric ganglion, and under some but not all conditions which accentuate hyperpolarization, the onset of tachyphylaxis was hastened. Jaramillo \& Volle (1968b) showed that when a ganglion was perfused with saline solutions containing $80 \mathrm{~mm}$ lithium chloride, or after treatment with ouabain, post-stimulation hyperpolarization did not occur, though (strangely) conduction was still blocked. In the present study, it was found that when the hypogastric ganglion was perfused with ouabain $(0.1 \mu \mathrm{g} / \mathrm{ml})$ or with modified saline solutions containing 80-100 mM lithium chloride, tachyphylaxis was rapidly reversed, and it was often possible to maintain the responses to TMA or DMPP for periods of up to 1 hour. A low sodium solution, without lithium but with equiosmolar sucrose did not have this effect. One other means of preventing hyperpolarization was the use of potassium-free solutions (Ritchie \& Straub, 1957; Rang \& Ritchie, 1968). It was found that this could also usually reverse tachyphylaxis after it had developed, but it was much less effective than lithium, and a secondary failure always occurred with further dosing.

A hyperpolarization block would also be consistent with the fact that both methacholine and tetanic preganglionic stimulation reverse tachyphylaxis even after a lapse of 15-20 minutes. Takeshige \& Volle (1964) showed that both methacholine and tetanic stimulation caused a prolonged ganglionic depolarization, and they believed that this explained the enhanced responses to acetylcholine that are seen following these treatments. It seems probable therefore that their depolarizing action would counteract the postulated hyperpolarization caused by the repeated doses of nicotinic stimulant drugs, thus restoring their stimulant action.

Techniques for accentuating post-stimulation hyperpolarization had rather inconsistent effects. These included perfusion with solutions containing 0-2.5 mM chloride ion (Rang \& Ritchie, 1968) where this was substituted with either sulphate or methylsulphate, or with saline containing $12.5 \mathrm{mM}$ potassium. This latter method not only did not hasten the onset of tachyphylaxis to TMA, but occasionally even reversed it. With the low chloride solutions, there were some experiments, especially with methyl sulphate, where tachyphylaxis occurred rapidly, and where a tetanic stimulation of the hypogastric nerve caused only a very brief reversal of the block. However, in some other experiments, this was not seen. Thus, while most of the evidence is consistent with the possibility that the tachyphylaxis is due to a hyperpolarization of the ganglion cells, other explanations must also be considered. Perry \& Reinert (1955) have shown that substances such as glutamate and aspartate which are involved in the transport of potassium across cell membranes, can affect the responses of denervated ganglion cells to various blocking drugs. These authors suggest that methonium compounds act by inhibiting an aerobic metabolic pathway. It is not impossible that the ultimate cause of the tachyphylaxis may also be some upset in the metabolism of the ganglion cells.

There is some evidence that muscarinic receptors are involved in ganglionic transmission (Gebber \& Snyder, 1968; Flacke \& Gillis, 1968), and Krstic (1972) has presented evidence that ganglionic receptors have properties intermediate between muscarinic and nicotinic. The ability of atropine to hasten the onset of tachyphylaxis to nicotinic stimulant drugs in the present experiments may be explained by supposing that it blocks muscarinic receptors in the ganglion. This is consistent with the observation that methacholine can reverse the tachyphylaxis and that the phenomenon is prevented by atropine. However, atropine does not prevent the reversal of tachyphylaxis by hypogastric nerve stimulation, $\mathrm{KCl}$ or histamine. Thus it must be concluded that although muscarinic receptors may participate in the reversal of tachyphylaxis, they are not essential for it. 


\section{References}

BENTLEY, G.A. (1972). Pharmacological studies on the hypogastric ganglion of the rat and guinea-pig. $\mathrm{Br}$. J. Pharmac., 44, 492-509.

FLACKE, W. \& GILLIS, R.A. (1968). Impulse transmission via nicotinic and muscarinic pathways in the stellate ganglion of the dog. J. Pharmac. exp. Ther., 163, 266-276.

GEBBER, G.L. \& VOLLE, R.L. (1966). Mechanisms involved in ganglionic blockade induced by tetramethylammonium. J. Pharmac. exp. Ther., 152, 18-28.

GEBBER, G.L. \& SNYDER, D.W. (1968). Observations on drug-induced activation of cholinoceptive sites in a sympathetic ganglion. J. Pharmac. exp. Ther., 163, 64-74.

HOLMAN, M.E., MUIR, T.C., SZURSZEWSKI, J.H. \& YONEMURA, K. (1971). Effects of iontophoretic application of cholinergic agonists and their antagonists to guinea-pig pelvic ganglia. Br. J. Pharmac., 41, 26-40.

HOLMES, O. (1962). Effect of $\mathrm{pH}$, changes in potassium concentration and metabolic inhibitors. Arch. int. de Physiol., 70, 211-245.

JARAMILLO, I. \& VOLLE, R.L. (1968a). A comparison of the ganglionic stimulating and blocking properties of some nicotinic drugs. Arch. int. pharmacodyn., 174, 88-97.

JARAMILLO, J. \& VOLLE, R.L. (1968b). Effects of lithium on ganglionic hyperpolarisation and blockade by dimethyl phenylpiperazinium. J. Pharmac. exp. Ther., 164, 166-175.

JONES, A. (1963). Ganglionic actions of muscarinic substances. J. Pharmac. exp. Ther., 141, 195-205.

KRSTIC, M.K. (1972). The action of choline on the superior cervical ganglion of the cat. Europ. J. Pharmac., 17, 87-96.

LANGLEY, J.N. (1891). On the course and connections of the secretory fibres supplying the sweat glands of the feet of the cat. J. Physiol., Lond., 12, 347-374.

LANGLEY, J.N. \& DICKINSON, W.L. (1889). On the local paralysis of peripheral ganglia, and on the connexion of different classes of nerve fibres with them. Proc. Roy. Soc., 46, 423-430.
McKINSTRY, D.N., KOENIG, E., KOELLE, W.A. \& KOELLE, G.B. (1963). The release of acetylcholine from a sympathetic ganglion by carbachol. Can. J. Biochem., 41, 2599-2609.

PATON, W.D.M. \& PERRY, W.L.M. (1953). The relationship between depolarisation and block in the cats superior cervical ganglion. J. Physiol., Lond., 119, 43-57.

PERRY, W.L.M. \& REINERT, H. (1955). On the metabolism of normal and denervated sympathetic ganglion cells. J. Physiol., Lond., 130, 156-166.

RANG, H.P. \& RITCHIE, J.M. (1968). On the electrogenic sodium pump in mammalian non-myelinated nerve fibres, and its activation by various external cations. J. Physiol., Lond., 196, 183-221.

RITCHIE, J.M. \& STRAUB, R.W. (1957). The hyperpolarisation which follows activity in mammalian non-medullated fibres. J. Physiol., Lond., 136, 80-97.

SMITH, J.C. (1966a). Observations on the selectivity of stimulant action of 4-( $m$-chlorophenylcarbamoyloxy)2-butynyltrimethyl ammonium chloride on sympathe tic ganglia. J. Pharmac. exp. Ther., 153, 266-275.

SMITH, J.C. (1966b). Pharmacologic interactions with 4-(m-chlorophenylcarbamoyloxy)-2-buty nyl trimethylammonium chloride, a sympathetic ganglion stimulant. J. Pharmac. exp. Ther., 153, 276-284.

TAKESHIGE, C. \& VOLLE, R.L. (1964). Modification of ganglionic responses to cholinomimetic drugs following preganglionic stimulation, anticholinesterase agents, and pilocarpine. J. Pharmac. exp. Ther., 146, 335-343.

TRENDELENBURG, U. (1954). The action of histamine and pilocarpine on the superior cervical ganglion and the adrenal glands of the cat. Br. J. Pharmac. Chemother., 9, 481-487.

TRENDELEN BURG, U. (1957). Reaktion sympathischen Ganglien wahrend der Ganglien blockade durch Nicotin. Naunyn Schmiedeberg's Arch. exp. Path. Pharmak., 230, 448-456. 